\title{
IMPACT OF THE MIS-TLIF TECHNIQUE ON THE SPINOPELVIC PARAMETERS OF PATIENTS WITH LUMBAR ARTHRODESIS
}

\author{
IMPACTO DA TÉCNICA MIS-TLIF NOS PARÂMETROS ESPINOPÉLVICOS DE PACIENTES \\ COM ARTRODESE LOMBAR
}

\author{
IMPACTO DE LA TÉCNICA MIS-TLIF SOBRE LOS PARÁMETROS ESPINOPÉLVICOS \\ DE PACIENTES CON ARTRODESIS LUMBAR
}

\author{
Cristiano Magalhäes Menezes, ${ }^{1,2}$ Leonardo Fernandes Aguiar, ${ }^{1,2}$ André de Oliveira Arruda, ${ }^{1}$ Rodrigo Vieira Cardoso, ${ }^{1}$ Germano Senna Oliveira do Valle, ${ }^{2}$ \\ Rodrigo Souza Lima, ${ }^{1}$ Mário Leite Bringel, ${ }^{1}$ Felipe Miranda Mendonça Fernandes, ${ }^{1}$ Joint Halley Guimbard Pérez ${ }^{1}$ \\ 1. Columna Instituto Dr. Cristiano Menezes, Belo Horizonte, MG, Brazil. \\ 2. Spine Surgery Group of the Hospital Ortopédico Lifecenter, Belo Horizonte, MG, Brazil.
}

\begin{abstract}
Objective: To evaluate the influence of the MIS-TLIF technique on the spinopelvic parameters of patients submitted to lumbar arthrodesis up to three levels for the treatment of vertebral degenerative conditions without deformity. Methods: Retrospective radiographic evaluation of 52 patients submitted to the surgical treatment of lumbar arthrodesis using the MIS-TLIF technique in up to three levels. The spinopelvic parameters - pelvic incidence (PI), pelvic tilt(PT), lumbar lordosis (LL), segmental lordosis (Lseg), and the difference between lumbar lordosis and pelvic incidence (LL-PI mismatch) were analyzed in orthostatic lateral radiographs in the pre- and postoperative periods, with a minimum follow-up of 1 year. The patients were divided into three groups: $\mathrm{PI}<45^{\circ}$, PI between $45^{\circ}$ and $55^{\circ}$ and $\mathrm{PI}>55^{\circ}$. Results: Sixty-nine operated levels were evaluated in 15 patients with $\mathrm{PI}<45^{\circ}, 19$ with $\mathrm{PI}$ between $45^{\circ}$ and $55^{\circ}$ and 18 with $\mathrm{PI}>55^{\circ}$. The mean value of the pelvic incidence was $52.3^{\circ}( \pm 11.5)$, lumbar lordosis $46.1^{\circ}$ (pre)/45.6 (post); segmental lordosis $20.3^{\circ}$ (pre)/20.6 (post); pelvic tilt $18.5^{\circ}$ (pre)/18.2 (post); "mismatch" (PI-LL) $7^{\circ}$ (pre)/ $6.6^{\circ}$ (post), with no statistical difference among all parameters ( $p>0.05)$. Conclusions: The MIS-TLIF technique had no influence on postoperative spinopelvic parameters of patients undergoing lumbar arthrodesis surgery. Level of evidence: III. Retrospective comparative study.
\end{abstract}

Keywords: Spinal curvatures; Spinal diseases; Spinal fusion; Arthrodesis.

\section{RESUMO}

Objetivos: Avaliar a influência da técnica MIS-TLIF nos parâmetros espinopélvicos de pacientes submetidos à artrodese lombar até três níveis para tratamento de condições degenerativas vertebrais sem deformidade. Métodos: Avaliação radiográfica retrospectiva de 52 pacientes submetidos a tratamento cirúrgico de artrodese lombar pela técnica MIS-TLIF em até três níveis. Os parâmetros espinopélvicos - incidência pélvica (PI), versão pélvica (PT), lordose lombar (LL), lordose segmentar (Lseg), diferença entre lordose lombar e incidência pélvica ("mismatch" PI-LL) foram analisados em radiografias em perfil ortostático no pré e pós-operatório, com segmento mínimo de 1 ano. Os pacientes foram divididos em três grupos: $\mathrm{Pl}<45^{\circ}$; $\mathrm{Pl}$ entre $45^{\circ}$ e $55^{\circ} \mathrm{e} \mathrm{Pl}>55^{\circ}$. Resultados: Foram avaliados 69 níveis operados $-\mathrm{Pl}<45^{\circ}, 15$ pacientes; $\mathrm{Pl}$

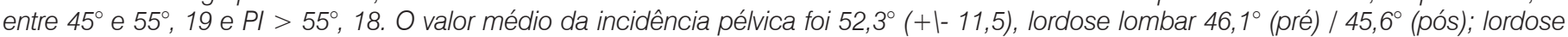

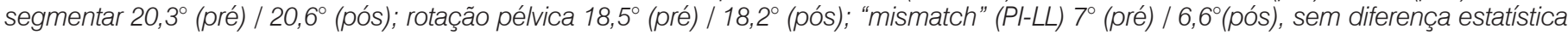
entre todos os parâmetros ( $p>0,05)$. Conclusão: A técnica MIS-TLIF não apresentou influência nos parâmetros espinopélvicos no pós-operatório de pacientes submetidos à cirurgia de artrodese lombar. Nível de evidência III. Estudo retrospectivo comparativo.

Descritores: Curvaturas da coluna vertebral; Doenças da coluna vertebral; Fusão vertebral; Artrodese.

\section{RESUMEN}

Objetivo: Evaluar la influencia de la técnica MIS-TLIF sobre los parámetros espinopélvicos de pacientes sometidos a artrodesis lumbar de hasta tres niveles para el tratamiento de condiciones vertebrales degenerativas sin deformidad. Métodos: Evaluación radiográfica retrospectiva de 52 pacientes sometidos a tratamiento quirúrgico de artrodesis lumbar por la técnica MIS-TLIF en hasta tres niveles. Los parámetros espinopélvicos como incidencia pélvica (IP), inclinación pélvica (PT), lordosis lumbar (LL), lordosis segmentaria (Lseg) diferencia entre lordosis lumbar e incidencia pélvica ("mismatch" LL-) se analizaron en radiografías laterales ortostáticas en el pre y postoperatorio, con seguimiento mínimo de 1 año. Los pacientes se dividieron en tres grupos: IP $<45^{\circ}$, IP entre $45^{\circ}$ y $55^{\circ}$ e IP $>55^{\circ}$. Resultados: Se evaluaron 69 niveles operados en 15 pacientes con IP $<45^{\circ}, 19$ con IP entre $45^{\circ}$ y $55^{\circ}$ y 18 con IP $>55^{\circ}$. El valor promedio de la incidencia pélvica fue

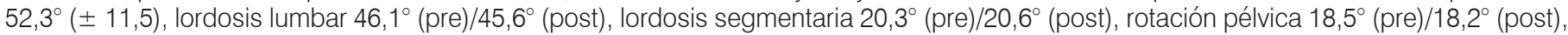
"mismatch" IP-LL $7^{\circ}$ (pre)/6,6 (post), sin diferencia estadística entre todos los parámetros ( $\left.\mathrm{p}>0,05\right)$. Conclusiones: La técnica MIS-TLIF no influenció los parámetros espinopélvicos en el postoperatorio de pacientes sometidos a cirugía de artrodesis lumbar. Nivel de evidencia: III. Estudio retrospectivo comparativo.

Descriptores: Curvaturas de la columna vertebral; Enfermedades de la columna vertebral; Fusión vertebral; Artrodesis.

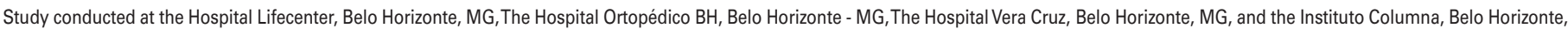
MG, Brasil.

Correspondence: Instituto Columna, Rua Conde de Linhares, 278 -Cidade Jardim, Belo Horizonte, MG, 30380-030. cristiano@ columnainstituto.com 


\section{INTRODUCTION}

The loss of lordosis and consequent change in the spinopelvic parameters are common in degenerative conditions that affect the lumbar spine..$^{1-4}$ Their analysis becomes highly important when considering surgical intervention, especially in terms of arthrodesis planning. The restoration of these parameters is related to better clinical and radiological results, with higher rates of fusion and a decrease in the incidence of adjacent level disease. ${ }^{5}$

There are several lumbar arthrodesis techniques, each with different possible approaches, such as anterior, lateral, and/or posterior. Among the interbody arthrodeses, the transforaminal (TLIF) is the most widely used, 6,7 and over the last decade, the minimally invasive technique (MIS-TLIF) has gained in popularity. Among its advantages, as compared to the traditional technique, less intraoperative bleeding, a shortened hospital stay, and early postoperative recovery stand out, in addition to interesting and compelling cost-effectiveness indices. ${ }^{8,9}$ Despite this, there are controversies in the literature around the ability of this technique to maintain and/ or increase segmental lordosis, exercising potential influence on the final spinopelvic parameters and thus affecting the clinical outcome. ${ }^{5}$

In this context, the objective of this study is to evaluate the impact of the standard MIS-TLIF technique on the radiographic spinopelvic parameters of patients with degenerative conditions as the therapeutic indication and who underwent surgical treatment for degenerative conditions of the lumbar spine at up to three levels.

\section{METHODS}

Following approval by the Institutional Review Board (no. 1.341.609), we conducted a retrospective, observational study, reviewing the medical records of patients who were submitted to spinal arthrodesis performed by a single surgeon from January 2008 to December 2012.

We included patients 18 years of age and above who underwent arthrodesis of from one to three levels and satisfied at least one of the following conditions: degenerative disc disease with or without disc herniation, canal stenosis, low-grade spondylolisthesis, and post-laminectomy/discectomy syndrome. The minimum follow-up for inclusion was 12 months. Patients with traumatic conditions, tumors, and severe associated deformities, with possible surgical indications in which the deformity would be the primary justification for intervention, were excluded.

The surgical technique used was described by Foley ${ }^{10,11}$ and also published previously in this journal. ${ }^{11-13}$

\section{Radiographical analysis}

Panoramic radiographs of the spine and/or the lumbosacral spine with the inclusion of the femoral heads in standing anterior-posterior (AP) and lateral (L) views were analyzed.

The following spinopelvic parameters were evaluated: pelvic incidence (PI), pelvic tilt (PT), lumbar lordosis (LL) (Figure 1), segmental lordosis (Lseg), and the difference between pelvic incidence and lumbar lordosis (mismatch $=\mathrm{PI}-\mathrm{LL}$ ).

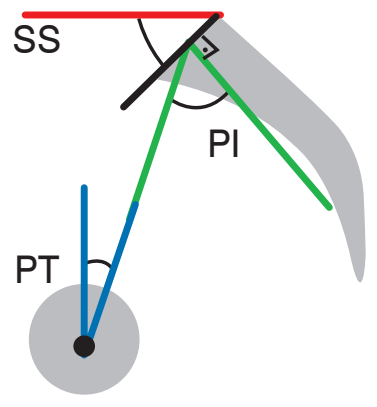

SS - sacral slope, PI - pelvic incidence, PT- pelvic tilt.

Figure 1. Schematic representation of the spinopelvic parameters.
In order to verify possible differences in the MIS-TLIF under different initial conditions, the patients were divided into three groups by range of pelvic incidence, namely, less than $45^{\circ}$ (low), between $45^{\circ}$ and $55^{\circ}$ (medium), and greater than $55^{\circ}$ (high).

All the radiographic measurements were performed by an independent spine surgeon and dubious cases were evaluated by a third-party researcher. The conventional terminology used in the literature was maintained, considering lordotic curves as negative values and kyphotic curves as positive.

\section{Statistical analysis}

As regards the statistical tests, absolute and relative frequencies were used to describe the qualitative variables, while measures of central tendency, position, and dispersion were used to describe the quantitative variables. For the comparison of the spinopelvic indices between the MIS-TLIF subgroups divided by ranges of $\mathrm{PI}$, the Student's t test was used for the normally distributed indicators and the Mann-Whitney test for the non-normal variables. Normality was verifying using the Shapiro-Wilk test.

\section{RESULTS}

The medical records of 52 patients were evaluated, of whom 22 were men and 30 were women, with a mean age of 53.5 years (ranging from 27 to 82 years), totaling 69 operated levels. (Table 1)

The mean value of pelvic incidence was $52.3^{\circ}$ (median 51.0 SD \pm 11.5 ). The values obtained for the other radiographic parameters follow. (Table 2)

The same parameters were analyzed with the division of patients according to the pelvic incidence values. For the group of patients with $\mathrm{Pl}<45^{\circ}(\mathrm{n}=15)$, a mean pelvic incidence of $40^{\circ}$ (standard deviation: 3.40 ) was obtained. The other radiographic parameters are presented in Table 3.

The comparison between the pre- and postoperative parameters can be confirmed according to the graphic representation in Figure 2.

In the group of patients with PI between $45^{\circ}$ and $55^{\circ}(n=19)$, the mean value of PI was $49.8^{\circ}$ (standard deviation: 3.40). The other radiographic parameters are presented in Table 4.

Table 1. List of number of patients by level analyzed.

\begin{tabular}{c|c}
\hline Levels & Number of patients evaluated \\
\hline L3-L4 (1 level) & 1 \\
\hline L4-L5 (1 level) & 21 \\
\hline L5-S1 (1 level) & 15 \\
\hline L3-L5 (2 levels) & 2 \\
\hline L4-S1 (2 levels) & 11 \\
\hline L3-S1 (3 levels) & 2 \\
\hline
\end{tabular}

Table 2. Radiographic parameters for the total population.

\begin{tabular}{c|c|c|c}
\hline $\begin{array}{c}\text { Radiographic } \\
\text { parameter }\end{array}$ & $\begin{array}{c}\text { Pre value } \text { ( }^{\circ} \text { ) } \\
\text { (n considered / } \\
\text { standard deviation) }\end{array}$ & $\begin{array}{c}\text { Post value } \text { ( }^{\circ} \text { ( } \\
\text { (n considered / } \\
\text { standard deviation) }\end{array}$ & P value \\
\hline $\mathrm{LL}$ & $46.1(n=35 / 10.2)$ & $45.6(n=52 / 10.1)$ & $>0.05$ \\
\hline $\mathrm{Lseg}$ & $20.3\left(\mathrm{n}^{*}=47 / 18.8\right)$ & $20.6\left(\mathrm{n}^{*}=69 / 7.5\right)$ & $>0.05$ \\
\hline $\mathrm{PT}$ & $18.5(\mathrm{n}=34 / 7.3)$ & $18.2(\mathrm{n}=51 / 8.6)$ & $>0.05$ \\
\hline Mismatch (PI-LL) & $7(\mathrm{n}=35 / 10.7)$ & $6.6(\mathrm{n}=52 / 10.7$ & $>0.05$ \\
\hline
\end{tabular}

* considered the total number of levels evaluated.

Table 3. Radiographic parameters for the population with $\mathrm{Pl}<45^{\circ}$.

\begin{tabular}{c|c|c|c}
\hline $\begin{array}{c}\text { Radiographic } \\
\text { parameter }\end{array}$ & $\begin{array}{c}\text { Pre value }\left(^{\circ}\right) \\
\text { (n considered / } \\
\text { standard deviation) }\end{array}$ & $\begin{array}{c}\text { Post value }\left(^{\circ}\right) \\
\text { (n considered / } \\
\text { standard deviation) }\end{array}$ & P value \\
\hline LL & $42.5(n=9 / 9.5)$ & $40.8(n=15 / 9.7)$ & $>0.05$ \\
\hline$L s e g$ & $20.3\left(n^{*}=12 / 6.3\right)$ & $19.7\left(n^{*}=21 / 8.5\right)$ & $>0.05$ \\
\hline PT & $12.8(n=9 / 5.2)$ & $12.1(n=15 / 6.1)$ & $>0.05$ \\
\hline Mismatch (PI-LL) & $-1.5(n=9 / 10.6)$ & $-0.8(n=15 / 10.3)$ & $>0.05$ \\
\hline$n^{*}$ considered the total number of levels evaluated.
\end{tabular}


The comparison between the pre- and postoperative values can be seen in Figure 3.

In the group of patients with $\mathrm{PI}>55^{\circ}(\mathrm{n}=18)$, we obtained a mean pelvic incidence value of $65.1^{\circ}$ (standard deviation: 7.69). The other radiographic parameters are presented in Table 5 below.

The comparison between the pre- and postoperative values can be seen in the following graph. (Figure 4)

\section{DISCUSSION}

The TLIF fusion technique, first described in 1998 by Harms and widely used since then, provides anterior support for the spine, posterior-lateral stabilization with pedicular instrumentation, direct visualization of the space to be approached, and decompression of

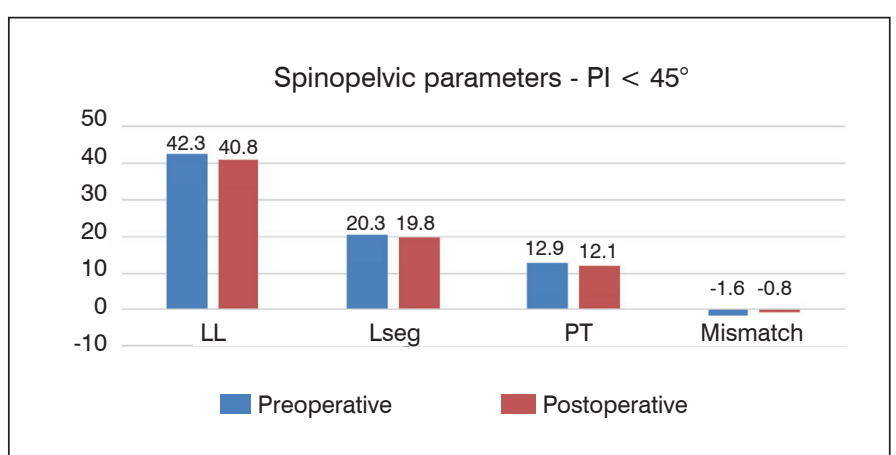

Figure 2. Comparison of pre- and postoperative spinopelvic parameters, $\mathrm{PI}<45^{\circ}$.

Table 4. Radiographic parameters for the population with PI between 45 and $55^{\circ}$.

\begin{tabular}{c|c|c|c}
\hline $\begin{array}{c}\text { Radiographic } \\
\text { parameter }\end{array}$ & $\begin{array}{c}\text { Pre value }\left(^{\circ}\right) \\
\text { (n considered / } \\
\text { standard deviation) }\end{array}$ & $\begin{array}{c}\text { Post value }\left(^{\circ}\right) \\
\text { (n considered / } \\
\text { standard deviation) }\end{array}$ & P value \\
\hline LL & $43.5(n=15 / 5.8)$ & $42.1(n=19 / 8.5)$ & $>0.05$ \\
\hline$L s e g$ & $18\left(n^{*}=34 / 6.5\right)$ & $19.2\left(n^{*}=47 / 6.8\right)$ & $>0.05$ \\
\hline PT & $17.5(n=14 / 4.7)$ & $17.8(n=18 / 6.2)$ & $>0.05$ \\
\hline Mismatch (PI-LL) & $6.2(n=15 / 7.1)$ & $7.7(n=19 / 9.2)$ & $>0.05$ \\
\hline
\end{tabular}

$n^{*}$ considered the total of the levels evaluated.

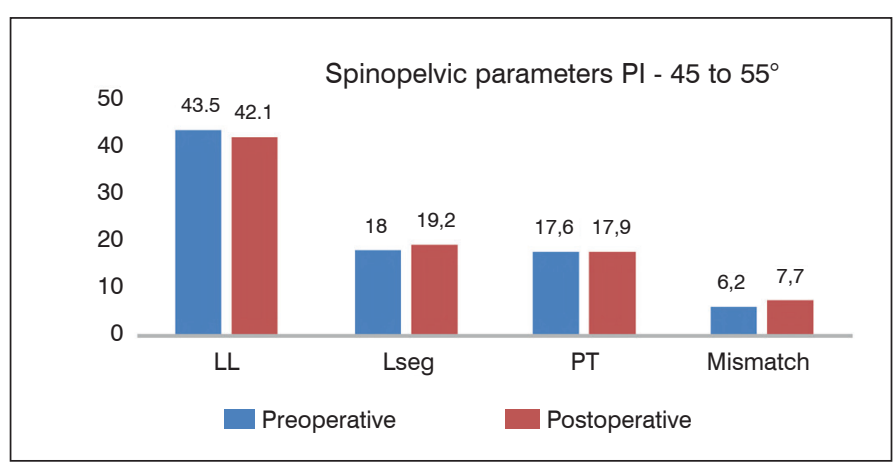

Figure 3. Comparison of the pre- and postoperative spinopelvic parameters, $\mathrm{Pl}$ between $45^{\circ}$ and $55^{\circ}$.

Table 5. Radiographic parameters for the population with $\mathrm{PI}>55^{\circ}$

\begin{tabular}{c|c|c|c}
\hline $\begin{array}{c}\text { Radiographic } \\
\text { parameter }\end{array}$ & $\begin{array}{c}\text { Pre value } \mathbf{~}^{\circ} \text { ) } \\
\text { (n considered / } \\
\text { standard deviation) }\end{array}$ & $\begin{array}{c}\text { Post value }\left(^{\circ}\right) \\
\text { (n considered / } \\
\text { standard deviation) }\end{array}$ & P value \\
\hline LL & $52.5(n=11 / 12.8)$ & $53.5(n=18 / 9.0)$ & $>0.05$ \\
\hline Lseg & $23.1\left(n^{*}=13 / 6.9\right)$ & $23.6\left(n^{*}=22 / 8.1\right)$ & $>0.05$ \\
\hline PT & $24.4(n=11 / 7.4)$ & $23.7(n=18 / 9.1)$ & $>0.05$ \\
\hline Mismatch (PI-LL) & $15.1(n=11 / 9.3)$ & $11.6(n=18 / 9.4)$ & $>0.05$ \\
\hline$n^{*}$ considered the total of levels evaluated.
\end{tabular}

Spinopelvic parameters $\mathrm{PI}>55^{\circ}$

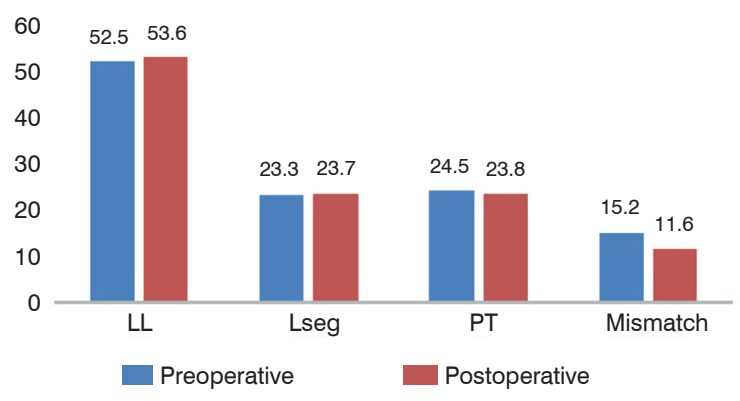

Figure 4. Comparison of the pre- and postoperative spinopelvic parameters, $\mathrm{PI}>55^{\circ}$

the nerve roots. ${ }^{14-17}$ Given these considerations, TLIF is recognized as a viable and feasible procedure for various degenerative spinal diseases. Degenerative spinal conditions are for the most part associated with segmental hypolordosis, mainly at levels L4-L5 and L5-S1, generating the use of compensatory mechanisms such as an increase in pelvic tilt (PT)..$^{15-19}$ Knowing that some patients cannot tolerate the smallest loss of lordosis when submitted to lumbar arthrodesis, the preoperative analysis of the spinopelvic parameters becomes essential, helping to determine the correction required and to choose the most appropriate surgical strategy. Minimally invasive TLIF was first described by Foley et al. ${ }^{10}$ and, since then, the use of the technique has grown exponentially. With the support of scientific literature, the less invasive technique offers results comparable to those of the traditional technique in terms of fusion rates and clinical results, with significant advantages in postoperative pain control, making possible early rehabilitation, shortened hospital stays, and lower complication rates. ${ }^{20-23}$ However, there are contradictions in the literature around the capacity of posterior arthrodesis techniques to correct the spinopelvic parameters, and even more so in relation to minimally invasive surgeries. In general, literature data are conflicting in relation to the capacity for the TLIF technique to both restore and maintain segmental lordosis. Hsieh et al. ${ }^{12}$ reported the mean loss of segmental lordosis following TLIF and attributed this lack of improvement to the difficulty in placing the interbody cage as anteriorly as possible, in addition to the presence of the intact contralateral facet joint, which prevents posterior compression. Kwon et al., ${ }^{15}$ in turn, reported the occurrence of TLIF-induced segmental kyphosis, justified by the more posterior placement of the cage in the disc interspace. In contrast, several authors have shown that a significant amount of endpoint segmental lordosis can be achieved placing the cage anteriorly and performing a bilateral facetectomy, ${ }^{14-16}$ while still maintaining the TLIF technique. Jong-Tae et al. ${ }^{19}$ analyzed the influence of straight and lordotic cages (interbody spacer) in 68 patients, concluding that the lordotic form is superior in relation to the increase in segmental lordosis and in maintaining disc height, providing better spinopelvic parameter results. In this study, the MIS-TLIF technique was not capable of significantly altering the parameters evaluated, effecting neither gains nor losses in lordosis following surgery.

Our study, similarly to other publications ${ }^{5,17}$ shows that MIS-TLIF does not have the ability to affect the angles of the spine and pelvis. Lafage et al. ${ }^{23}$ reported that the increase in PT correlates directly to worse functional results in patients with spinal deformity and revealed that an increase in PT is directly linked to pain following lumbar arthrodesis. Khoi D. Than et al. ${ }^{20}$ showed that better clinical results are associated with the restoration of the spinopelvic parameters, with greatest significance when the SVA (sagittal vertical axis) $<5$ $\mathrm{cm}$ and the PI-LL mismatch is less than 10.

To date, few studies have evaluated the radiological results following TLIF and/or MIS-TLIF procedures, with emphasis on 
postoperative sagittal alignment and on spinopelvic parameters. In their case series of 45 patients, Mourad Ould-Slimane et al. ${ }^{5}$ showed that TLIF was capable of acting locally (effect on the segment), increasing disc height and segmental lordosis, with a correction of pelvic rotation, but that there was no significant modification, i.e., improvement in sagittal alignment, at the global level. Thus, in cases of severe deformity associated with important sagittal changes, the use of other techniques to achieve correction should be considered.

All the patients evaluated in this study were operated by the same surgeon with extensive experience in minimally invasive techniques, since these techniques require a considerable learning curve and the clinical and radiological results can be directly influenced according to the surgeon's familiarity with the materials and processes involved in surgical planning and execution. The positioning of the cage in the interbody space was not analyzed, given that during the study period the oblique-type cage was routinely positioned in the center of the disc space. No posterior release procedures or associated osteotomies were performed.
Statistically, MIS-TLIF was not able to restore lordosis or even cause curve loss in any of the different PI range groups.

The sample used in this study was comparable to those of other works published in the literature. The main limitations are the absence of a control group and the lack of functional results measurements.

\section{CONCLUSION}

The standard MIS-TLIF technique had no restorative effect on lumbar lordosis, nor was it responsible for any loss of lordosis in the operated segments. There was no postoperative influence on the spinopelvic parameters and the preoperative values were maintained.

All authors declare no potential conflict of interest related to this article.

CONTRIBUTION OF THE AUTHORS: Each author made significant individual contributions to this manuscript. CMM (0000-0001-6670-5159)* performed the surgeries and contributed to the design of the study; LFA (0000-0002-1347-2758)*, AOA (0000-0001-6579-8234)*, RVC (0000-0002-8377-2887)*, GSOV (0000-0003-2253-7450)*, RSL (0000-0002-7778-2616)*, MLB (0000-0001-5531-5569)*, FMMF (0000-0002-5692-788X)*, and JHGP (0000-00028887-8947)* followed-up on the patients and compiled the clinical data; CMM (0000-0001-6670-5159)* and AOA (0000-0001-6579-8234)* reviewed the statistical analysis data; RVC (0000-0002-8377-2887)*, CMM (0000-0001-6670-5159)*, and AOA (0000-0001-6579-8234)* performed the bibliographical review and reviewed the manuscript. *ORCID (Open Researcher and Contributor ID).

\section{REFERENCES}

1. Jang JS, Lee SH, Min JH, Han KM. Lumbar degenerative kyphosis: radiographic analysis and classifications. Spine (Phila Pa 1976). 2007;32(24):2694-9.

2. Takemitsu Y, Harada Y, I wahara T, Miyamoto M, Miyatake Y. Lumbar degenerative kyphosis. Clinical, radiological and epidemiological studies. Spine (Phila Pa 1976). 1988:13(11):1317-26.

3. Glassman S, Berven S, Bridwell K, Horton W, Dimar J. Correlation of radiographic parameters and clinical symptoms in adult scoliosis. Spine (Phila Pa 1976). 2005;30(6):682-8.

4. Mehta V, Amin A, Omeis I, Gokaslan Z, Gottfried O. Implications of spinopelvic alignment for the spine surgeon. Neurosurgery. 2012;70(3):707-21.

5. Ould-Silmane M, Lenoir T, Dauzac C, Rillardon L, Hoffmann E, Guigui P, et al. Influence of transforaminal lumbar interbody fusion procedures on spinal and pelvic parameters of sagittal balance. Eur Spine J. 2012;21(6):1200-6.

6. Harms J, Rolinger H. A one-stage procedure in operative treatment of spondylolistheses: dorsa traction-reposition and anterior fusion [in German] Z Orthop Ihre Grenzgeb. 1982:120(3):343-7.

7. Rosenberg WS, Mummaneni PV. Transforaminal lumbar interbody fusion: technique, complications, and early results. Neurosurgery. 2001;48(3):569-74.

8. Foley KT, Lefkowitz MA. Advances in minimally invasive spine surgery. Clin Neurosurg. 2002:49:499-517.

9. Goldstein CL, Phillips FM, RampersaudYR. Comparative Effectiveness and Economic Evaluations of Open Versus Minimally Invasive Posterior or Transforaminal Lumbar Interbody Fusion. A Systematic Review. Spine (Phila Pa 1976). 2016:41 Suppl 8):74-89.

10. Foley KT, Holly LT, Schwender JD. Minimally Invasive Lumbar Fusion. Spine. 2003;28:S26-35.

11. Menezes CM, Junior MAF, Falcon RS, Oliveira DA, Freire SG. Experiência inicial com a técnica de artrodese lombar minimamente invasiva por via transforaminal (MIS TLIF). Coluna/Columna. 2007:6(3):141-8.

12. Menezes CM, Junior MAF, Falcon RS, Oliveira DA. Artrodese minimamente invasiva para espondilolisteses de baixo grau. Coluna/Columna. 2008;7(3)241-5

13. Menezes CM, Junior MAF, Falcon RS, Alencar J. Avaliação clínica radiológica da artrodese lombar transforaminal aberta versus minimamente invasiva. Coluna/Columna. 2009;8(3):297-302
14. Hsieh P, Koski T, O'Shaughnessy BA, Sugrue P, Salehi S, Ondra S, et al. Anterior lumbar interbody fusion in comparison with transforaminal lumbar interbody fusion: implications for the restoration of foraminal height, local discangle, lumbar lordosis and sagittal balance. J Neurosurg Spine. 2007;7(4):379-86.

15. Kwon B, Berta S, Daffner S, Vaccaro A, Hilibrand A, Grauer J, et al. Radiographic analysis of transforaminal lumbar interbody fusion for the treatment of adult isthmic spondylolisthesis. J Spinal Disord Tech. 2003;16(5):469-76.

16. Jagannathan J, Sansur C, Oskouian R, Fu KM, Shaffrey C. Radiographic restoration of lumbar alignment after transforaminal lumbar interbody fusion. Neurosurgery. 2009;64(5):955-63.

17. Lee DY, Jung TG, Lee SH. Single-level instrumented mini-open transforaminal lumbar interbody fusion in elderly patients. J Neurosurg Spine. 2008;9(2):137-44.

18. Yson S, Santos ERG, Sembrano J, Polly D. Segmental lumbar sagital correction after bilateral transforaminal lumbar interbody fusion. J Neurosurg Spine. 2012:17(1):37-4

19. Jong-Tae K, Myung-Hoon S, Ho-Jin L, Du-Yong C. Restoration of lumbopelvic sagital alignmentand its maintenance following transforaminal lumbar interbody fusion (TLIF): comparison between straight type versus curviliner type cage. Eur Spine J. 2015:24(11):2588-96.

20. Than KD, Park P, Fu KM, Nguyen S, Wang MY, Chou D, et al. Clinical and radiographic parameters associated with best versus worst clinical outcomes in minimally invasive spinal deformity surgery. J Neurosurg Spine. 2016; 25(1):21-5.

21. Groth AT, KukloTR, Klemme WR, Polly DW, Schroeder TM. Comparison of sagittal contour and posterior disc height following interbody fusion: threaded cylindrical cages versus structural allograft versus vertical cages. J Spinal Disord Tech. 2005:18(4):332-6.

22. Peng CW, Yue WM, Poh SY, Yeo W, Tan SB. Clinical and Radiological Outcomes of Minimally Invasive Versus Open Transforaminal Lumbar Interbody Fusion. Spine (Phila Pa 1976). 2009;34(13):1385-9.

23. Lafage V, Blondel B, Smith JS, Broachie-Adiei O, Hostin RA, Burton D, et al.. Preoperative planning for pedicle subtraction osteotomy: Does pelvic tilt matter? Spine Deform. 2014;2(5):358-66. 